\title{
Real Estate: Foundations of the Ontology of Property
}

\author{
Barry Smith and Leo Zaibert
}

\begin{abstract}
Suppose you own a garden-variety object such as a hat or a shirt. Your property right then follows the age-old saw according to which possession is nine-tenths of the law. That is, your possession of a shirt constitutes a strong presumption in favor of your ownership of the shirt. In the case of land, however, this is not the case. Here possession is not only not a strong presumption in favor of ownership; it is not even clear what possession is. Possessing a thing like a hat or a shirt is a rather straightforward affair: the person wearing the hat or shirt possesses the shirt or the hat. But what is possession in the case of land? This essay seeks to provide an answer to this question in the form of an ontology of landed property.
\end{abstract}

\section{The Boundaries of Landed Property: How Far Does Your Property Extend?}

In his far-reaching study of property rights, Richard Pipes discusses the etymology of 'possession' and cognate terms. He tells us:

Some primates assert exclusive claims to land by physically occupying or "sitting" on it. This behavior is not so different from that of humans, as indicated by the etymology of words denoting possession in many languages. Thus, the German verb for "to own", besitzen, and the noun for "possession", Besitz, literally reflect the idea of sitting on or, figuratively, settling upon. The Polish verb posiadać, "to own", as the noun posiadłość, "property", have an identical origin. The same root underpins the Latin possidere, namely sedere, "to sit", from which derive the French posséder and the English "to possess". The word "nest" derives from a root (nisad or nizdo) signifying "to sit". The monarch occupying the throne has been described as engaging in "nothing else but the symbolic act of sitting on the realm" (Pipes, 1999, 68) 
In this passage Pipes correctly emphasizes the "symbolic" and "figurative" nature of this "sitting on" and "settling upon" the land. For his purposes it is not important to ask how much land a person (or primate) possesses (or owns) by symbolically sitting on it. It is unlikely that the person would be claiming exclusivity only over the surface of the land he is actually touching. Much more likely is it that a person would claim exclusivity over a region much larger than the area in actual contact with his body. And the symbolic practice of sitting gives absolutely no clue as to what the extension and boundaries of the land over which the person is claiming exclusive rights might be. Thus, the object a person claims to possess or to own is not well defined. Note that this factor of indeterminacy or uncertainty in the borders of one's property has no analogue in the realm of shirts and hats. It is geographic in nature.

It is our purpose in what follows to stress the special character that landed property exhibits amongst the many forms of property rights. Understanding this special character will then shed light on what is needed for a more adequate account. Such an account must encompass not only the dimension of law but also those of politics and economics (Stubkjaer, 2001). Here we seek to lay bare the foundations of the needed full ontology of landed property.

\section{The Politics of Landed Property: What Can We Own?}

The crucial importance for political affairs of landed property (or real estate, we shall use these two expressions interchangeably) has been eloquently summarized by Rousseau:

The first person who, having fenced a plot of ground, took it into his head to say this is mine and found people simple enough to believe him, was the true founder of civil society. (Rousseau, 1992, 44).

There are two aspects to Rousseau's view that deserve special attention; one concerns geography, the other ontology; more precisely the ontology of social reality. First, the act of fencing off need not, in the context of this passage, be restricted to the case where some physical boundary is constructed. It can be seen as including also the establishment of fiat boundaries - for example when you tell people where the borders of your property lie, or when you simply mark its corners (Smith, 2001). To fence a plot of land is to create something new. The land itself, of course, exists before the parcel is plotted, but the act of fencing off nonetheless creates a new object. Second, this act 
alone is not sufficient for such object-creation. The latter requires also the existence of what John Searle calls collective intentionality (Searle 1995); that is, it requires that other persons (simplemindedly or not) believe that the land is indeed the property of he who fenced it off. Only then can a property right be said to arise.

This means that a comprehensive study of landed property will have three interconnected dimensions:

(1) a geographic dimension, having to do with the peculiarities of the ways in which real estate is related to the land itself (and thus also with the issue of boundaries);

(2) a cognitive dimension, having to do with the interrelations between such geospatial phenomena and our culturally entrenched beliefs and convention;

(3) an ontological dimension, having to do with what real estate is.

We can throw some light on the latter by considering first of all the more general question of what can be the object of a property right of any sort. Let us use the term 'thing' to refer to anything that can in principle be owned. The German legal philosopher Adolf Reinach provides a useful first analysis of this notion, pointing out that:

The concept of a thing [Sache] in no way coincides with that of a bodily object, even if positive enactments would restrict it to this. Everything which one can "deal" with, everything "usable" in the broadest sense of the word, is a thing: apples, houses, oxygen, but also a unit of electricity or warmth, but never ideas, feelings or other experiences, numbers, concepts, etc. (Reinach 1983, 53).

Reinach's passage carries the suggestion that, even though the concept of thing is not to be identified with that of a bodily object, still: things must be concrete. Abstract entities such as numbers and concepts fall outside the range of what can be owned. As Reinach himself would have accepted, however, it is perfectly possible that entities such as computer programs, architectural designs, and so forth be owned. And even leaving aside such issues of intellectual property, we shall see that there is an important further class of abstract entities - rights themselves - which fall within the domain of what is ownable.

Reinach suggests that being "usable" might be a necessary condition for something's being ownable; but it is not a sufficient condition. There is a long list of objects regarding which it is difficult to say whether they can be 
owned, though it is clear that these objects can be used in varied ways. Do we own ourselves? We have certain rights over our bodies, but are they property rights? (Munzer 1994, 1995) Whether or not human corpses, body parts, children, can be owned are difficult questions to answer (Ryan 1994). But the difficulties associated with the idea of ownership in such entities are of a different sort from those which arise in the case of land. The limitations which many societies place on the ownership of human corpses stem from religious and ethical views, not, for example, from any difficulty in ascertaining the boundaries of corpses. Similarly, limitations on the right to commercialize our body parts seem to stem from ethical considerations rather than from any ontological difficulty in determining the boundary of, say, a lung. (Such a geographic dimension may, though, arise in relation to the buying and selling of fetuses, where we do indeed face a difficulty in determining the boundary between fetus and mother (Smith and Brogaard 2002).) We shall here, however, leave aside the discussion of those objects which are excluded from being ownable as a result of moral and religious views, and concentrate exclusively on the case of ownership in land.

The first step in trying to analyze land as an object that can be owned is to appeal to the age-old distinction between movable and immovable things. Land is the quintessential immovable thing. (The German term for real estate law is "Immobilienrecht".) The term 'real estate' refers precisely to those immovable things which are the objects of rights. But, is land really immovable? For lawyers and legal scholars, this question must surely seem absurd, and they will answer it without hesitation in the affirmative. From a more sophisticated ontological perspective, however, matters are not so clear. For there is a range of types of immovable things whose treatment will shed light upon the partly fictional nature of the (positive) legal concept of immovability.

The standard classification of immovables stipulates four types:

1) Immovables by nature, the paradigmatic examples of which are land-parcels, edifices (including buildings) and plants adhering to the soil.

2) Immovables by destination; here the best examples are agricultural machinery, animals associated with cultivation, and so on. These are all movable things that the law 'immobilizes' in order to account for the strict relationship of dependence in which these objects stand to other objects which are deemed immovables by nature. 
3) Immovables by the object to which they are applied; this category pertains to rights. This is a bold fiction of the law, for as Planiol points out: "rights, being incorporeal are, strictly speaking neither movables nor immovables. They are not tangible. They take up no room" (Planiol 1930, 317). A classification of rights into movable and immovable can therefore be made only by attending to the object to which the right applies. If the right applies to an immovable thing, then the right is deemed immovable; if the right applies to a movable thing then the right is deemed movable.

4) Immovables by declaration; finally, the category of immovables by declaration is the most fictional of all categories of immovable things, since here immovability is just a consequence of some individual's whim. Someone may, for example, simply declare some specific good to be immovable (for example, someone may declare an artwork in her own house to be immovable). There are stark differences from country to country in the way immovables by declaration are provided for and dealt with.

As can be clearly seen, the extent to which the immovability of an object depends on legal fictions varies considerably in the four cases mentioned. But it is hardly ever admitted that even in the case of land there is an element of fiction involved in its putatively immovable nature, and even in those rare cases where this element is indeed admitted, it is not further investigated. Planiol, for example, refers to that which is immovable by nature as follows:

Strictly speaking, there is nothing which is absolutely immovable. Even the elements which compose the soil, rocks, sand, minerals, may be displaced. When a canal is dug, when lots are leveled it is the soil which is transported. In America, engineers have displaced large buildings without demolishing them. In Paris, the fountain $d u$ Palmier on the Place $d u$ Châtelet was set back in its entirety to permit the opening of the Boulevard de Sebastopol. But the law does not envisage the possibility of movement with the same rigor as mechanics. The law holds those things to be immovable [by nature] which are immovable in a durable and habitual manner and whose function is to be immovable, even if they may be displaced, in some cases, by extraordinary means. (Planiol 1930, 306). 
Land moves, too, of course, with the movement of the earth (and a comprehensive analysis of land must take account of this fact if it is to do justice to the extension of property rights in land to the moon, or to distant planets, or even to entire sub-divisions of the cosmos). Even when we take account of the many fictions which it might be politically or economically or astronomically fruitful to allow, however, we must conclude that the initially plausible distinction between movables and immovables has only limited potential as the cornerstone of a rigorous analysis of landed property.

\section{The Economics of Landed Property: What Can We Do With What We Own?}

The economic effects of landed property are huge. A recent and comprehensive study (De Soto, 2000) highlights many of these effects. The central thesis of de Soto's book, which is entitled The Mystery of Capital, is that things do not amount to capital. Not even land amounts to capital. For as he points out: "In Asia, Africa, the Middle East, and Latin America [...] most of the poor already possess the assets they need to make a success of capitalism" (Op. cit., 2000, 5). The problem is that "they hold these resources in defective forms: houses built on land whose ownership rights are not adequately recorded, unincorporated businesses with undefined liability, industries located where investors cannot see them" (Op. cit., 2000, 5-6).

What De Soto seeks is an ontology of capital, along the same lines as the ontology of real estate that we sketch here. The crucial question that De Soto tries to answer is How do we transform things into capital? And of all the things that are so transformed, the most important, indeed the foundational one, is land. De Soto's book is provocatively wide-ranging and impressively researched; but its perspective is that of the economist, not that of the philosopher-ontologist, and it is precisely the latter that is needed if we are to make sense of the matters to which he draws attention.

De Soto, rightly, points out that those surprisingly abundant assets that the poor have in third world nations "cannot readily be turned into capital, cannot be traded outside of narrow circles where people know and trust each other, cannot be used as collateral for a loan, and cannot be used as a share against an investment" (De Soto, 2000, 6). This is an extremely important point: the poor lack capital, but they do not necessarily lack assets (some of the poor could, of course, lack both, though the empirical evidence collected by De Soto strongly suggests that it is a lack of capital which is the problem). As a matter of fact, the difference between successful and unsuccessful nations, 
from the economic perspective, runs skew to the degree of development of their mechanism for turning stuff into capital.

Unfortunately, De Soto sometimes betrays the letter of his own thesis: he refers to these non-capitalized assets at times as "non-capital" and at other times (more frequently) as "dead capital" or as "undercapitalized assets" Of course, it might turn out that De Soto wishes that we understand these expressions as synonyms; nonetheless, it would be better if we had clear indications as to what exactly non-capital is, what capital is, what dead or dormant capital is (if such things exists) and how they all fit together within a single unified theory. And such a theory requires further a foundation in an ontology of real estate - for (as becomes clear through the course of De Soto's study) it is rights over land that are of paramount importance.

De Soto compares economically weak and underdeveloped nations to economically robust nations. The following holds only for the latter: "every parcel of land, every building, every piece of equipment, or store of inventories is represented in a property document that is the visible sign of a vast hidden process that connects all these assets to the rest of the economy" (De Soto, 2000, 6). Though De Soto makes reference here to different types of objects and not only to land, it is clear that land is the most important of the objects which he seeks to investigate. It is not only the fact that "the single most important source of funds for new businesses in the United States is a mortgage on the entrepreneur's house", and that mortgages are, in principle, applicable only to real estate (De Soto, 2000, 6). De Soto admits the primordial role of real estate also when, in explaining the comprehensive research agenda that led him and his associates to Egypt, Peru, Russia, Haiti, and the Philippines, he states that: "To be more confident of our results, we focused our attention on the most tangible and detectable of assets: real estate" (De Soto, 2000, 30). What De Soto's research shows, in the end, is that a plausible and fruitful way to express the difference between developed and under-developed nations is the degree to which land is turned into real estate (and, of course, the degree to which that system which turns land into real estate then allows for further transactions with the fully capitalized parcels which result).

By "raw land" in what follows we shall understand not real estate which is being under-utilized but rather physical land (of any sort) before it has become real estate. We can then affirm with De Soto that the cornerstone of the mechanism for turning raw land into real state - that is for turning stuff 
into capital - is a representational system made up of titles, deeds, registration documents, and so forth.

De Soto rightly insists that the representational system which is the basis of the formation of capital is not simply a collection of "stand-ins for the assets": "a formal property representation such as a title is not a reproduction of the house, like a photograph, but a representation of our concepts about the house" (De Soto, 2000, 50). An advantage of such representations is that, unlike physical assets, they are "easily combined, divided, mobilized, and used to stimulate business deals" (De Soto, 2000, 56). But the most salient advantage of these representations is that they have the power to transform raw land into that multi-layered entity which is a parcel of real estate - or in other words to give rise to a plurality of ontologically distinguishable aspects of what is, from a geometrical point of view, identically the same piece of land. They thereby allow the fully capitalized assets to enjoy a multiple existence; namely, a physical existence, a legal existence, an economic existence, a political existence, and so forth. Compare De Soto's remarks on the differences between dwellings in economically developed and economically underdeveloped nations. In the latter, people's houses serve at best to protect them from the weather or from wild animals and criminals. In economically developed nations, in contrast, people's "houses no longer merely keep the rain and cold out. Endowed with representational existence these houses can now lead a parallel life, doing economic things they could not have done before" (De Soto, 2000, 62-63).

It is clear then, that developing an accurate and efficient system of representation for land parcels, and of the transactions regarding these parcels, is a necessary condition for the functioning of capitalism in its developed form, and indeed of that transition to fully functioning capitalism which is economic development. Yet, as we shall see, the construction of such a system is not an easy task.

\section{Collective Intentionality, Rules, and the Ontology of Property}

Let us return to Rousseau's famous dictum quoted at the beginning of this essay. It is not only fencing off a plot of land that is important; important also is the fact that people believe that the person who fenced this plot of land is also the one who actually owns it. Collective intentionality is necessary for the existence of landed property. This is a crucial element of the ontology of property rights. 
A recent and powerful attempt to apply ontological tools to the analysis of unorthodox entities like landed property is carried out by John Searle in his The Construction of Social Reality (Searle, 1995). Searle draws a distinction, first of all, between brute facts and institutional facts. Brute facts are those facts which exist independently of human conventions. Institutional facts are a sub-set of social facts; social facts are, simply those that depend on human conventions for their existence. The additional, special characteristic of institutional facts is that they involve the creation, extension or transfer of powers. Searle does not distinguish between rights and powers; as a matter of fact, whenever he speaks of powers in the realm of institutional facts he really means what are normally referred to as rights in our sense (for having a power, in the more usual sense, is typically a matter of brute facts, say, the power to invade your property). For the moment, nonetheless, we shall follow Searle in stating that the primitive term in the creation of social reality is power.

All institutional facts require collective intentionality. That certain rectangular pieces of paper count as money requires that there is a group of people who believe that they do so. (Which group of people is relevant for this purpose and how large it needs to be are difficult problems, which Searle does not discuss.) That Susan is French, that Manuel is Mexican are institutional facts, since nationalities, too, require collective intentionality. (That two plus two equals four, in contrast, is a brute fact, since it does not require collective intentionality.) That someone owns the shirt he is wearing requires collective intentionality, and so does the fact that someone owns a plot of land.

Searle has also put forth a now familiar distinction between what he calls regulative and constitutive rules. The former, as he puts it, merely regulate antecedently existing forms of behaviour. For example, the rules of polite table behavior regulate eating, but eating itself exists independently of these rules. Some rules, on the other hand, do not merely regulate; they also create or define new forms of behaviour. The rules of chess create the very possibility of our engaging in the type of activity we call playing chess. The latter is just: acting in accordance with the given rules.

Constitutive rules, Searle tells us, 'always have the same logical form ... They are always of the logical form such-and-such counts as having the status so-and-so'. (Searle 1999, pp. 123 f) An utterance of the form 'I promise ...' counts as putting oneself under a corresponding obligation. A given 
relationship between a person and a plot of land, counts as ownership. And as we see from these cases, the $\mathrm{Y}$ term in a constitutive rule characteristically marks something that has consequences in the form of rewards, penalties, or actions one is obliged to perform in the future.

When applying the $\mathrm{X}$ counts as $\mathrm{Y}$ formula we have to take into account whole systems of such rules. Acting in accordance with all or a sufficiently large subset of these and those rules by individuals of these and those sorts counts as conducting a legal trial according to Massachusetts law. The counts as formula can also be iterated so that whole systems of iterated structures (including the system we call property in land) can arise, systems which interact in multifariously spreading networks. Consider for example the way in which the marriage and inheritance systems have interacted with the landed property system in different cultures over time.

Searle's account of the way in which so much in human civilization rests in this way on systems of integrated and interleaved constitutive rules is certainly the most impressive theory of the ontology of social reality we currently have. But this account is also not without its problems, and the discussion of these problems sheds light on the ontology of landed property. For Searle's social ontology in its original form presupposes that - as in the case of President Clinton and Canterbury Cathedral and the money and driver's license in your pocket - the X terms at the bottom of the hierarchy are in every case parts of physical reality. When we examine the detailed workings of his theory, however, we discover that Searle is committed also to the existence of what we might call 'free-standing Y terms', or in other words to entities which do not coincide ontologically with any part of physical reality. One important class of such entities is illustrated by what we loosely think of as the money in our bank accounts as this is recorded in the bank's computers. In The Construction of Social Reality we find the following passage:

all sorts of things can be money, but there has to be some physical realization, some brute fact - even if it is only a bit of paper or a blip on a computer disk - on which we can impose our institutional form of status function. Thus there are no institutional facts without brute facts (Searle 1995, 56).

On closer inspection, however, it becomes clear that blips in computers do not really count as money and nor can we use such blips as a medium of exchange. Rather, as Searle has subsequently acknowledged, blips in computers are merely representations of money, and as he points out, it 
would be 'fascinating project to work out the role of these different sorts of representations of institutional facts'. (Searle 2002)

Searle here recognizes a new dimension in the scaffolding of institutional reality, the dimension of representations. As the blips in the bank's computers merely represent money, so the deeds to your property merely record or register the existence of your property right. The deed is not identical with your property right and nor does it count as your property right. An IOU note, similarly, records the existence of a debt; it does not count as the debt. It is an error to run together records pertaining to the existence of free-standing $\mathrm{Y}$ terms with those free-standing Y terms themselves.

As the case of money shows, some social objects have an intermittent and what we might think of as a merely generic realization. Others, such as corporations or universities, have a physical realization that is partial and also scattered (and also such as to involve a certain turnover of parts). Yet others, such as debts, may have no physical realization at all; they exist only because they are reflected in records or representations (including mental representations). A full-dress ontology of social reality must address all of the different types of cases mentioned, from $Y$ terms which are fully identical with determinate parts of physical reality to $\mathrm{Y}$ terms which coincide with no determinate parts of physical reality at all.

Free-standing $\mathrm{Y}$ terms, as might have been predicted, are especially prominent in the higher reaches of institutional reality, and especially in the domain of economic phenomena, where we often take advantage of their abstract status in order to manipulate them in quasi-mathematical ways. Thus we pool and securitize loans, we depreciate and collateralize and amortize assets, we consolidate and apportion debts, we annualize savings - and these examples, along with the already mentioned example of the money existing (somehow) in our banks' computers, make it clear that the realm of freestanding Y terms must be of great consequence for any theory of institutional reality.

That this is so is made abundantly clear not least by De Soto's work which was indeed in part inspired by The Construction of Social Reality and which also goes some way towards realizing Searle's 'fascinating project' of working out the role of the different sorts of representations of institutional facts. As De Soto shows, it is the 'invisible infrastructure of asset management' upon which the astonishing fecundity of Western capitalism rests, and this invisible infrastructure consists precisely of representations, for example of the property records and titles which capture what is economically 
meaningful about the corresponding assets - representations which in some cases serve to determine the nature and extent of the assets themselves. (See Smith and Zaibert, 2001.)

Capital itself, in De Soto's eyes, belongs precisely to the family of those free-standing Y terms which exist in virtue of our representations:

Capital is born by representing in writing - in a title, a security, a contract, and other such

records - the most economically and socially useful qualities [associated with a given asset]. The moment you focus your attention on the title of a house, for example, and not on the house itself, you have automatically stepped from the material world into the conceptual universe where capital lives (De Soto 2002, pp. 49 ff.).

As those who live in underdeveloped regions of the world well know, it is not physical dwellings which serve as security in credit transactions, but rather the equity that is associated therewith. The latter certainly depends for its existence upon the underlying physical object; but there is no part of physical reality which counts as the equity in your house. Already the term "negative equity" should draw our attention to the special nature of this phenomenon. Equity is tied to time, to history, and to a certain portion of physical reality; yet it is at the same time something abstract, something that exists only insofar as it is represented in a legal record or title in such a way that it can be used to provide security to lenders in the form of liens, mortgages, easements, or other covenants in ways which give rise to new types of institutions such as title and property insurance, mortgage securitization, bankruptcy liquidation, and so forth.

\section{The Uniqueness of Landed Property}

Landed property in general is nestled in a much more complicated system of constitutive rules, and it requires more variegated forms of collective intentionality than do other forms of property. There is a sense in which the existence of any right whatsoever requires collective intentionality. Unless one believes in the existence of some form of natural law which would imply the existence of rights independent of any human conventions, any right requires for its existence that people believe that it is indeed a right. In the simplest case, someone might have property rights over the shirt he is wearing. The only aspect of this situation that requires collective 
intentionality is that relating to the institutional fact: this person owns this shirt. In the case of property in land, however, collective intentionality is required not only at the level of the person owning the land but also with respect to the existence of the very plot of land itself. For here it is not only the property right itself that requires collective intentionality, but also the object over which the right falls.

We suspect that this explains Rousseau's characteristically malicious suggestion that the people who would believe that the plot of land is indeed the property of the person who fenced it off are simpletons - people who have been duped. It would have been less easy for Rousseau to make this same point in respect to, say, those of his fellows who believed that Rousseau himself was the owner of the shirt on his back. This is because, in relation to the ownership of the shirt, there is one level only that is subject to collective intentionality. In relation to the plot of land, in contrast, it is not only in the existence of the right of property that we have to believe, but also in the existence of the very object over which the property right falls - an object which is supposed to be somehow created by the very act of fencing off.

Some political discussions regarding property rights do indeed recognize the distinction between landed and other forms of property. For example Henry George called for the institution of a 'single tax' on land, on the grounds that one cannot legitimately own naturally occurring resources, but can only have rights to the value one adds through one's own work - a proposal that has been endorsed in our own day by Hillel Steiner (1994). And as Richard Pipes reminds us, John Stuart Mill

questioned whether land should be treated as merely one particular form of property, on the grounds, first, that no one had made it, and second, that whereas in creating movable wealth one did not deprive one's fellowmen of an opportunity to do likewise, in appropriating land one excludes others (Pipes 1999, 57).

The contrast drawn by George is far from being absolute, however. Thus it may take work (and the adoption of considerable risks) to discover natural resources such as gold, and land, and if all natural resources were to count as common property, then much of this work (and risk) would not be forthcoming. Mill's criterion of excludability is on the right track. But it captures only part of what is, from the ontological point of view, a much more complex phenomenon. 


\section{What is a Property Right?}

Property rights are complex sets of other rights, and excludability is only one of the many rights in the bundle, and land is different from other forms of property also for reasons which have to do with features of this complex set. Property is often conceived, à la Hohfeld (1919), after the model of a bundle of sticks. Each stick in the bundle signifies a particular right or power: a right to use, a right to possess, to sub-divide, to rent, to build upon, to enjoy the usufruct from, and so on. An owner can, in certain cases, sell or give away specific rights, or see these rights removed, divided, or amended by the force of others. Our practical dealings with landed property in cases where the sticks have dwindled or been transformed in this fashion can be a very complex matter. It is important to point out, however, that the absolute property right itself is in no way affected by this dwindling of the rights (or powers) that make up the property right. This means that Hohfeld's 'bundle' analogy is in fact not quite correct, though we shall find it useful to employ his terminology nonetheless. As Reinach has eloquently put it:

If property were a sum or unity of rights, it would be reduced by the alienation of one of these rights, for a sum necessarily disappears with the disappearance of all its parts. But we see that a thing continues to belong to a person in exactly the same sense, however many rights he may want to alienate; it makes no sense at all to speak of a more or less with respect to belonging. The nuda proprietas in no way means that the owning "springs back to life" once the rights transferred to other persons have been extinguished; the thing rather belongs to the owner in the interval in exactly the same sense as before and after ... This is the essential necessity which underlies the so-called "elasticity" or "residuarity" of property and which can hardly be reasonably considered as an "invention" of the positive law (Reinach, 1987, 56).

Each of the sticks that make up the property right can, in principle at least, be the object of negotiations independently of the remaining sticks in the bundle, and whatever the outcome of such negotiations the property right - the absolute relation of belonging - remains ontologically speaking intact. Someone can give away some of the sticks without giving away his property over the thing in question. Thus it is not uncommon to see cases in which someone has given away (or has had taken away) virtually all the sticks in the 
bundle (in the case, for example, of the possession of his land by squatters); but even then his residual property right over the thing itself remains.

The bundle of property rights in land has first of all the elastic or residual character that has been referred to already above. Such elasticity is manifested to some degree in other spheres, for example in the car rental or equipment leasing markets. But it still seems odd to suppose that someone might give away the right to use a washing machine or toothbrush for long periods of time while retaining title to the goods in question. In most such cases it seems that, when someone gives away a specific stick from the bundle, then he is actually giving away the full right of property over the object in question.

Two interconnected reasons explain why it is especially in the case of landed property that this residual character is essential. First, some types of negotiations relating to the sticks in the bundle make practical sense only in relation to landed property. Although the owner of, say, a painting, or a car, strictly speaking has the right to subdivide it, it seems unlikely that he will ever seek to exercise this right.

Second, it is primarily in relation to landed property that the mentioned maneuvers (subdividing, commercializing the fruits of, etc.) are commonly carried out, precisely because there are here more sticks in the bundle, and they are more varied and complex than in relation to other types of property. Leasing, time-sharing, owning shares in a social club, borrowing, subdividing, using as collateral are examples which illustrate just some of the possibilities here. And because of the central economic importance of land as the presupposition of all other human activity, it is only in the case of landed property that correspondingly complex legal institutions have grown up in reflection of the different dimensions of rights involved.

Consider, for example, my property right over my watch: it is easy to see that the bundle of sticks which comprises this property right can only be altered with difficulty - and even then still only partially. We cannot, after all, meaningfully talk about subdividing, or building upon a watch, or harvesting the usufruct therefrom. What purpose could be served by giving away the possession or the use of the watch while maintaining ownership over it? The age-old aphorism 'possession is nine tenths of the law' is, under this light, exactly right. While ownership and possession are closely related phenomena, the relationship between them is much closer in the case of movables than in the case of immovables. 
A further important reason for the differences between landed property and other types of property turns on the special geographic dimension of the objects of property rights in land. As we have seen, the idea of a parcel of land is in greater need of ontological clarification than is, say, that of a watch or a lawnmower. A parcel of land, we can now say, has fiat boundaries, and this means: it needs to have its boundaries provided for by some human institutions. A full-blown ontological analysis of real estate must thus provide an account not only of the make-up of the bundle of sticks which comprises a property right in general, but also of the accompanying institutions for example of boundary maintenance and title and cadastral registration. It must also provide an account of the interplay between these dimensions - and this in such a way as to do justice also to the differences between different human cultures. The analysis in question must accordingly have at least the following components, each one of which will be seen to have been at work in the arguments above:

a) When someone owns a parcel of real estate, then there is a certain portion of the surface of the earth to which he is related.

b) This portion of land must have the character of an enduring object which - at least when considered on the scale of human events endures permanently.

c) This portion of land must have definite, known (or at least knowable) boundaries.

d) The portion of land must be such that the owner, and in principle others, may gain (legal and physical) access.

e) The portion of land must be knowable. Investors and others must know where it is situated

f) Real estate gives rise to neighbors. There are no neighbors where there is raw land, simply because they are no boundaries in raw land. Even the so-called bona fide boundaries - those obvious discontinuities on the surface of the earth, such as coastlines, mountain ranges, rivers, etc., are not boundaries in the sense which pertains to the ontology of real estate - until someone considers them to be so.

g) Parcels of real estate have different conditions of identity than do raw land. I might exchange all the soil in my land in New York for the soil in your land in Delaware, yet I would still be the owner of real estate in New York and you in Delaware. 
h) A parcel of real estate is multi-layered in the sense that there are ontologically distinguishable aspects of what is, from a geometrical point of view, identically the same piece of land. There are layers of geology, of archeology, of history, of ecology, of rights of way, and so on, as well as layers of insurance, equity, and economic value; and the state can own (or have property rights in) some or all of these layers even in those circumstances where a private person is the ostensible owner of the plot of land simply conceived.

i) A parcel of real estate is a three-dimensional solid which includes regions above and below the surface of the earth itself. As an owner of a parcel of real estate I must for example have the right to prohibit my neighbor from building a structure that would invade the space above my land. This feature illustrates most clearly the institutional (fiat) character of real estate. For even in regard to pure geometry, the specification of the height and depth of the relevant three-dimensional solid differs from culture to culture. In the United States, for example, the owner of a given parcel in fact (and in law) owns a cone-shaped region of space projecting from the center of the earth and reaching upwards (roughly) as far as the ear can hear. In other places these determinations are effected in different ways. One of the specific prerogatives which the state has in Latin America is that it owns the whole of the subsoil in the country, no matter who owns the surface of the land.

j) The boundaries of a land parcel are affected by a factor which we might call crispable vagueness - that is by a vagueness that can, where necessary for practical reasons, be alleviated by institutional fiat or by negotiation. (Smith, 2001) If someone owns a land-parcel in Venezuela, and finds gold some few inches below the ground, this gold becomes the property of the state. Of course, this presents the state with the problem of determining how to fix the boundary between the surface and the subsoil. It seems odd, to say the least, that a hand-made hole of merely a few inches constitutes a penetration in the state's exclusive property. Note that the problem faced by even developed institutions of property law in providing a clear demarcation of such a boundary is analogous to the problem of drawing a line between, say, territorial and extraterritorial waters. Fiat crisping will occur only where it is of practical importance. Cadastral and title registration, for example, is much more precise 
and reliable in countries, such as Switzerland or Austria or Holland, were land is scarce, than it is in the US or Australia or (presumably) Siberia.

\section{Appendix: Apriorism, Realism, and the Ontology of Landed Property} In The A Priori Foundations of the Civil Law, Reinach sought to attack the view that the concepts and structures of the civil law were created by the civil law, that is, that they were merely the reflections of laws as created human institutions. Reinach, in contrast, sought to show that "the positive law finds the legal concepts which enter into it; in absolutely no way does it produce them [emphasis in the original]" (Reinach, 1983, 4). Thus, Reinach attacks precisely the sort of view that Searle puts forth. Reinach further tells us that specifically legal structures "have a being of their own just as much as numbers, trees, or houses" and "that this being is independent of its being grasped by men" (Reinach, 1983, 4). There are true propositions in the realm of the law, he held, and these propositions are true independently of anyone knowing that they are true and of anyone deciding to create the concepts to which the propositions refer.

Reinach's thus embraces a doctrine of apriorism regarding the basic building blocks of the legal realm, a doctrine which he takes as providing a bulwark against legal positivism, legal relativism and related positions. Reinach is thus not merely a realist about legal institutions. A realist in regard to a given domain holds that there are facts pertaining to that domain which obtain independently of whether or not they are recognized as obtaining. Reinach goes further in embracing legal apriorism: he holds, in other words, that there is a special way in which we come to know these recognitiontranscendent facts.

"If there are legal entities and structures which in this way exist in themselves", Reinach points out, "then a new realm opens up here for philosophy. Insofar as philosophy is ontology of the a priori theory of objects, then it has to do with the analysis of all possible kinds of object as such" (Reinach, 1983, 6). True to this goal, most of Reinach's book is devoted to an analysis of basic legal concepts such as claim, right, obligation, promise, property, and so on. In light of Reinach's analysis, moreover, law resembles certain other disciplines: like "pure mathematics and pure natural science there is also a pure science of law" (Reinach, 1983, 6). Already in 1869 Ernest Beling, Reinach's teacher, had attempted an aprioristic analysis of the 
criminal law in his Die Lehre Vom Verbrechen. Carl Menger attempted to deploy apriorism as a basis for the science of economics and in this he represents faithfully the spirit of the so-called "Austrian School", which he founded (see Menger 1871).

The connection between Reinach's apriorism and the ontology of landed property can now be explained as follows. Given the multilayered ontology of landed property, Searle's simple ontology based on collective intentionality cannot do the work. Someone owning a given plot of land is not, under normal circumstances, affected by the collective beliefs of any group, even though those beliefs were perhaps necessary to set up the relevant system of landed property in the first place. He may just own the land, independently of the beliefs of those around him. While collective intentionality is thus perhaps crucial for the creation of institutional reality, and also for the resolution of disputes concerning this reality, it is not so important for the continued existence of this reality in the normal case. Moreover, there are important aspects of the phenomenon of real estate which are not the result of human agreements of any sort. Rather, they are part and parcel of the underlying structure of real estate as such, a structure which is intelligible to beings like ourselves, not because we have created it but because, like the structures of promising, claim, obligation, debt, and so forth, and also like the structures of circle, square, triangle, hypotenuse, it is there waiting to be discovered In Reinach's words, there are certain basic legal entities and structures

which exist independently of the positive law, though they are presupposed and used by it. Thus the analysis of them, the purely immanent, intuitive clarification of their essence, can be of importance for positive-legal discipline. The laws, too, which are grounded in their essence, play a much greater role within the positive law than one might suspect. One knows how often in jurisprudence principles are spoken of which, without being written law, are "self-evident", or "follow from the nature of things" to mention only a few of these expressions. In most cases it is not a matter of principles whose practical usefulness or whose justice is fully evident, but rather the essential structures investigated by the apriori theory of right. They are really principles which follow from 
the "nature" or "essence" of the concepts in question.

(Reinach, 1983, 6-7)

That an obligation ceases to exist after it has been discharged is a principle that has nothing to do with any agreement between men; the validity of this principle does not presuppose intentional states of any kind. If someone understands the concept of obligation, he will ipso facto realize that it would make no sense to suggest that someone under an obligation to do $\mathrm{X}$ remains obligated after doing X. Similarly, and more concretely, that real estate must have boundaries, or that it must give rise to neighbors, or, in general, that the ontology of real estate must do justice to the characteristics listed above, is not an empirical discovery (or the product of some convention) but rather a matter of the intelligible structure of the domain in question. It should be clear how Reinach's approach differs from that of Searle. While there is no doubt that Searle provides a valuable analysis of the ontological structures underlying many institutional phenomena, his framework allows too much to be the result of fiat and convention. And in fulfilling the task of the ontology of real estate we need to take into account not only those dimensions of the realm of landed property which are conventional in nature, but also those dimensions which are prior to all conventions - and which thus make these conventions possible.

\section{References}

Beling, Ernest. (1964) Die Lehre Vom Verbrechen, Tübingen: Scientia Verlag Aalen.

Bentham, Jeremy. (1958) "Principles of the Civil Code", in John Bowring, (ed.), The Works of Jeremy Bentham, Vol. 1, New York: Russell and Russell.

Bittner, Steffen, Wolff, Annette von, Frank, Andrew U. (2000) "The Structure of Reality in a Cadastre", in Berit Brogaard (ed.), Rationality and Irrationality (Papers of the 23rd International Wittgenstein Symposium), Kirchberg am Wechsel: Austrian Ludwig Wittgenstein Society, 88-96.

De Soto, Hernando. (2000) The Mystery of Capital, New York: Basic Books.

Hohfeld, Wesley. (1913) "Some Fundamental Legal Conceptions as Applied in Judicial Reasoning" Yale Law Review 23.

Mark, David M., Smith, Barry and Tversky, Barbara. (1999) "Ontology and Geographic Objects: An Empirical Study of Cognitive Categorization", in C. Freksa and David M. Mark (eds.), Spatial Information Theory. 
Cognitive and Computational Foundations of Geographic Information Science (Springer Lecture Notes in Computer Science 1661), 283-298.

Menger, Carl. (1871) Grundsätze der Volkswirtschaftlehre, Vienna: Braumüller.

Munzer, Stephen R. (1995) A Theory of Property, Cambridge: Cambridge University Press.

Munzer, Stephen R. (1994) "An Uneasy Case Against Property Rights in Body Parts" Paul, Ellen Frank et al. (eds.).

Nozick, Robert. (1974) Anarchy, State and Utopia, New York: Basic Books. Pipes, Richard. Properly and Freedom, New York: Vintage, 1999.

Planiol, Marcel. (1939) Treatise on the Civil Law, Lousiana State Law Institute translation).

Reinach, Adolf. (1983) "The A Priori Foundations of the Civil Law" Aletheia (3): 1-143.

Rousseau, Jean-Jacques. (1992) Discourse on the Origins of Inequality, Indianapolis: Hackett.

Ryan Alan. (1994) "Self Ownership, Autonomy, and Property Rights" in Paul, Ellen Frankel et al. (eds.).

Searle, John R. (1995) The Construction of Social Reality, New York: Free Press.

Smith, Barry, (1990) "The Question of Apriorism", Austrian Economics Newsletter: 1-5.

Smith, Barry (1992) "An Essay on Material Necessity”, in P. Hanson and B. Hunter, eds., Return of the A Priori (Canadian Journal of Philosophy, Supplementary Volume 18).

Smith, Barry. (2001) "Fiat Objects", Topoi, 20: 2, September 2001, 131-148.

Smith, Barry (forthcoming) "Ontology", in Luciano Floridi (ed.), Blackwell Guide to Philosophy, Information and Computers, Oxford: Blackwell.

Smith, Barry and Brogaard, Berit 2002 "Sixteen Days", The Journal of Medicine and Philosophy.

Smith, Barry and Mark, David M. 1999 "Ontology with Human Subjects Testing: An Empirical Investigation of Geographic Categories", American Journal of Economics and Sociology, 58: 2, 245-272.

Smith, Barry and Mark, David M. 2001 "Geographic Categories: An Ontological Investigation", International Journal of Geographic Information Science, forthcoming.

Smith, Barry and Zaibert, Leo. "The Metaphysics of Real Estate", Topoi 20 (2001): 161-172. 
Spector, Mary B. (1986) "Vertical and Horizontal Aspects of Takings Jurisprudence: Is Airspace Property?", Cardozo Law Review 7: 489-518.

Steiner, Hillel. (1994) An Essay on Rights, Oxford: Blackwell.

Stubkjær, Erik (2001) 'Spatial, Socio-Economic Units and Societal Needs Danish Experiences in a Theoretical Context", in A. Frank et al. (eds.), The Life and Motion of Socio-Economic Units (GISDATA 8), London: Taylor and Francis, 265-280.

Thomasson, Amie L. (1999) Fiction and Metaphysics, Cambridge: Cambridge University Press.

Zaibert, Leo. (1999) "Real Estate as an Institutional Fact: A Philosophy of Everyday Objects", American Journal of Sociology and Economics, 58: 2, 273-284. 